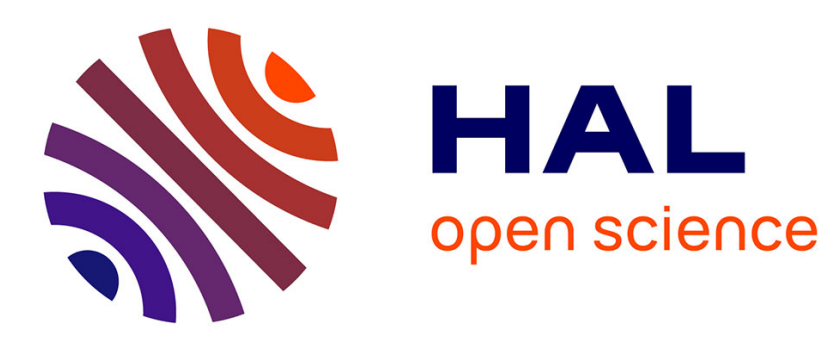

\title{
Partial Employment Protection and Perceived Job Security: Evidence from France
}

Alexandre Georgieff, Anthony Lepinteur

\section{To cite this version:}

Alexandre Georgieff, Anthony Lepinteur. Partial Employment Protection and Perceived Job Security:

Evidence from France. 2017. halshs-01519772

\section{HAL Id: halshs-01519772 \\ https://shs.hal.science/halshs-01519772}

Preprint submitted on 9 May 2017

HAL is a multi-disciplinary open access archive for the deposit and dissemination of scientific research documents, whether they are published or not. The documents may come from teaching and research institutions in France or abroad, or from public or private research centers.
L'archive ouverte pluridisciplinaire HAL, est destinée au dépôt et à la diffusion de documents scientifiques de niveau recherche, publiés ou non, émanant des établissements d'enseignement et de recherche français ou étrangers, des laboratoires publics ou privés. 


\section{PARISSCHOOL OF ECONOMICS}

WORKING PAPER N² 2017 - 18

Partial Employment Protection and Perceived Job Security: Evidence from France

Alexandre Georgieff

Anthony Lepinteur

JEL Codes: J28, J38, I31

Keywords: Employment Protection, Perceived Job Security, Difference-inDifference

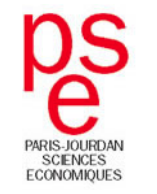




\title{
Partial Employment Protection and Perceived Job Security: Evidence from France*
}

\author{
Alexandre Georgieff (PSE) ${ }^{\dagger}$ \\ Anthony Lepinteur (PSE - CES)‡
}

Friday $5^{\text {th }}$ May, 2017

\begin{abstract}
This paper assesses the causal effect of partial employment protection on workers' subjective job security via the perceived probability of layoff. We consider the rise in the French Delalande tax, which is paid by private firms if they lay off older workers. This reform was restricted to large firms and therefore allows us to use a difference-indifference strategy. In ECHP data, we find that the change in the perceived probability of layoffs induced by the higher Delalande tax improved the subjective job security of older (protected) workers, but at the cost of a negative externality on younger (unprotected) workers. While the fall in perceived job security of younger workers is mirrored by actual increase in their layoff rate, the rise in perceived job security of older workers is more puzzling because we do not observe a reduction in their layoff rate.
\end{abstract}

Keywords: Employment Protection, Perceived Job Security, Difference-in-Difference. JEL Classification Codes: J28, J38, I31.

${ }^{*}$ We are particularly indebted to Andrew Clark and Claudia Senik. We are also grateful to Philippe Askenazy, Fabrice Etilé, Paul Frijters, Marc Gurgand, David Margolis, Barbara Petrongolo and Gilles SaintPaul.

${ }^{\dagger}$ Paris School of Economics, 48 boulevard Jourdan, 75014 Paris, France. Contact: alexandre.georgieff@psemail.eu

${ }^{\ddagger}$ Paris School of Economics - Université Paris 1 Panthon-Sorbonne, 48 boulevard Jourdan, 75014 Paris, France. Contact: anthony.lepinteur@psemail.eu 


\section{Introduction}

There is by now a great deal of empirical evidence that employment protection reduces job and worker flows ${ }^{1}$. We here ask whether this affects workers' perceived job security, both positively for those who are covered and negatively for those who are not. These are important questions as we know that workers' subjective evaluations of their job predict their labourmarket behaviour (Freeman (1978), Akerlof et al. (1988), Clark, Georgellis \& Sanfey (1998), Clark (2001))) and may affect firm outcomes such as productivity and profit (Harter, Schmidt \& Hayes (2002)). The existing empirical literature on the relationship between employment protection and the subjective perception of job security has mostly relied on cross-country analysis, and generally finds a negative correlation (Böckerman (2004), Postel-Vinay \& SaintMartin (2004), Clark \& Postel-Vinay (2009)). This surprising result can be explained by the perverse effects of employment protection, in particular via less job creation. Subjective job security is related to both separations and hirings (Böckerman, Ilmakunnas \& Johansson (2011)), via the transition probabilities between employment and unemployment.

This paper complements existing work by using a natural experiment to assess the causal impact of partial employment protection on workers' self-assessed job security. We focus on changes in the perceived probability of layoff from a French employment-protection reform implemented in 1999: an increase in the Delalande tax, which is paid by private-sector firms if they lay off workers aged over 50 in permanent contracts. This 1999 rise was restricted to firms with more than 50 employees, and as such provides a natural quasi-experiment that can be analysed via difference-in-difference estimation. We consider private-sector workers with permanent contracts in European Community Household Panel (ECHP) survey data. These data cover the period 1994-2001. We should emphasize that this estimation does not allow us to examine the effect of the reform through job creation and perceived job-finding probabilities, as workers in large firms might be hired in small firms later on, and vice versa. We here assess the effect of partial protection through layoff probabilities only.

Our main finding is that the change in the cost of layoffs from the higher Delalande tax led to greater feelings of job security for protected workers, but at the cost of less job security for other workers. The job security movements are of similar size for both groups, at $10 \%$

\footnotetext{
${ }^{1}$ See among others Kugler et al. (2002), Gómez-Salvador, Messina \& Vallanti (2004), Boeri \& Jimeno (2005), Autor, Kerr \& Kugler (2007)
} 
of a standard deviation. As there are far more unprotected than protected workers, the rise in the Delalande tax reduced aggregate job security. The largest fall in job security is for unprotected workers who are closer to 50, as this is the group that firms have the greatest incentive to lay off (before they become covered by the Delalande tax).

There are two issues that our empirical analysis needs to address. The first is the French reform of mandatory weekly working hours. In 1998, the French Ministry of Labour announced that there would be a reduction of standard weekly hours from 39 to 35 hours in firms with over 20 employees; this reform was enacted in 2000. These expected changes may therefore have affected perceived job security in firms with over 20 employees in our ECHP data from 1998 onwards. We however show that the difference in subjective job security between firms with less than and more than 50 employees (which is the threshold for the Delalande tax) is also found when we drop workers from firms with under 20 employees (i.e. when we restrict the sample to include only firms that were subject to the 35-hour week).

Second, macro-economic trends may produce different changes in job security in large and small firms. We address this issue by taking advantage of the cross-country dimension of ECHP data. We replicate the identification strategy in bordering countries and show that the difference-in-difference estimates there are insignificant.

Our results highlight that the perverse effects of partial employment protection on the perceived job security of unprotected workers may more than offset its beneficial effects on protected workers. In addition, as we do not consider the negative effects of protection on job creation, our estimates of these perverse effects constitute a lower bound.

The remainder of the paper is organized as follows. Section 2 presents the institutional background and the theoretical implications, while Section 3 describes the ECHP data that we use. Section 4 explains the empirical strategy, and the main results and robustness checks respectively appear in Section 5 and 6. Last, Section 7 concludes. 


\section{Institutional Background, Theoretical Implications and Ex- pected Impacts}

\subsection{Institutional Background}

The Delalande tax was proposed and introduced in the French legislative system in 1987 to restore the financial balance of the unemployment-insurance system and reduce the rise in the layoffs of older workers. Despite numerous changes over time, the principle of the tax has remained unchanged: firms laying off workers of over a certain age have to pay the Delalande tax to the unemployment-insurance system. This tax is proportional to the worker's gross wage and covers private-sector workers with permanent contracts. From 1987 to 1992, the tax amount was three months of gross wages for all workers aged over 55 .

The first major changes to this tax were introduced in July 1992. Table 1 shows how the tax profile has changed. In particular, in 1992 the tax started to depend on firm size, the age threshold of workers covered was lowered to 50, and the maximum tax amount increased to 6 months of gross wages. However, workers who were hired after age 50 and had been unemployed for at least 3 months were exempt from the tax. Additional changes to the tax scheme were made in January 1993 and January 1999. From 1993 to December 1998, the tax did not depend on firm size but only the worker's age. In January 1999, the tax was increased for firms with over 50 employees only. This increase was announced by the French government one year beforehand. ${ }^{2}$

\subsection{Theoretical Implications of Partial Employment Protection and Ex- pected Effects on Perceived Job Security}

Theoretical analysis (see among others Mortensen \& Pissarides (1999), Cahuc \& PostelVinay (2002)) predicts that employment protection reduces job and worker flows. The intuition behind this is summarized in Cahuc \& Postel-Vinay (2002):

"Higher firing costs limit job destruction by making layoffs more expensive, while they also inhibit job creation by reducing the overall expected profitability of jobs" (p.79)

\footnotetext{
${ }^{2}$ According to the article entitled "Pénalisation des licenciements des plus de 50 ans : le projet de Martine Aubry" published in the French newspaper Les Echos in 1998, the increase in the Delalande tax was not expected, especially by unions even though they were satisfied by this reform.
} 
This prediction has been confirmed in a variety of empirical contributions ${ }^{3}$.

Following Mortensen \& Pissarides (1994) and Pissarides (2000), Behaghel (2007) proposes a stochastic job-matching model that accounts for the Delalande tax. ${ }^{4}$ This tax reduces both the separation rate and the probability of a return to work for older workers, while it increases the separation rate and reduces the probability to return to work for younger workers.

Behaghel, Crépon \& Sédillot (2008) test these theoretical predictions on hirings and layoffs using French data from the Labour Force Survey. We here extend these predictions to workers' perceived job security, and focus only on the separation channel: we specifically ask how the 1999 rise in the Delalande tax affected worker's subjective job security by changing their perceived probability of layoff. We expect two effects in large firms as the tax rises. First, lower separation rates should increase the perceived job security of workers aged over 50 . On the contrary, higher separation rates should reduce the job security of younger workers. ${ }^{5}$

\section{Data}

Our data come from the European Household Community Panel (ECHP). The ECHP is a longitudinal survey carried out in 15 European countries, including France. A nationally representative sample of household and individuals was interviewed each year between 1994 and 2001 in each country. In France, on average 15,000 individuals were surveyed per wave. The interviews mainly took place between October and December.

The ECHP contains detailed information on socio-economic characteristics, incomes, employment conditions, social relations and so on. ${ }^{6}$ The rise in the Delalande tax in 1999 only applied to workers aged over 50 in firms with over 50 employees. We identify the covered respondents in the ECHP by their reported age in the survey (we correct misreporting by comparing birth and interview dates). The size of the firm in which the respondent works, measured by the number of employees in the firm, is recorded in the following categories::

\footnotetext{
${ }^{3}$ See Kugler et al. (2002), Dolado, García-Serrano \& Jimeno (2002), Blanchard \& Landier (2002), GómezSalvador, Messina \& Vallanti (2004), Boeri \& Jimeno (2005), Autor, Kerr \& Kugler (2007), Kugler \& Pica (2008).

${ }^{4}$ The main differences from previous models are segmentation of the labour market into age sub-markets, each of which has its own matching function, and the inclusion of firing costs for older workers. See Behaghel (2007) for more technical details.

${ }^{5}$ There is of course also an effect on hiring, as with any transaction tax on the labour market. By the construction of the Law, this hiring effect applies to all age groups equally.

${ }^{6}$ More details are available on http://ec.europa.eu/eurostat/web/microdata/european-communityhousehold-panel
} 
"None", "1 to 4", "5 to 19", "20 to 49", "50 to 99", "100 to 499" and "500 or more".

The ECHP also contains a number of questions on job domain satisfaction. Subjective job security is our main dependent variable, and is measured by the following question:

"How satisfied are you with your present job in terms of job security?"

Respondents answered on a 6-point scale, 1 meaning "Not Satisfied" and 6 meaning "Fully Satisfied". Figure 1 shows the distribution of subjective job security. It can be seen that $70 \%$ of responses are 4 or 5 . This negative skewness is commonly found for satisfaction measures.

Our main sample consists of adult respondents working in the private sector with permanent contracts, and with valid information on job characteristics and perceived job security. We restrict the sample to workers who do not cross the age 50 threshold during the posttreatment sample period (i.e. who were born before September 1949 or after December 1951), and who were hired when under 50. We thus split the sample into two age groups with clear "treatment" nature: workers who are either protected (older workers) or not protected (younger workers) during the whole post-reform sample period. This leaves us with 14,110 observations based on 3,003 individuals. The complete descriptive statistics appear in Tables A.1 and A.2 in the Appendix.

\section{Identification Strategy and Empirical Specification}

Our main goal here is to assess the causal effect of partial employment protection on worker's subjective job security via changes in the perceived probability of layoff. To do so, we exploit the firm-size discontinuity induced by the Delalande tax reform implemented in 1999: the layoff tax paid to the unemployment-insurance system rose for firms with over 50 employees but remained unchanged for firms with under 50 employees. This reform provides a natural quasi-experimental design for difference-in-difference (D-i-D) estimation, in which workers in large firms constitute the treatment group and those in smaller firms the control group. We propose first to estimate the following standard D-i-D equation, which only distinguishes between larger and smaller firms:

$$
J S_{i t}=\alpha+\beta_{1}\left(B F_{i t} * \text { Post }_{t}\right)+B F_{i t}+\beta_{2} X_{i t}+\mu_{i}+\lambda_{t}+\epsilon_{i t}
$$


Here $J S_{i t}$ is the subjective job security of a worker $i$ at year $t, X_{i t}$ a vector of individual socio-demographic controls (age and age-squared, marital status, number of children, and region dummies) and $\lambda_{t}$ years fixed-effects. This equation also controls for individual fixedeffects $\mu_{i}$. As the outcome is a subjective assessment of job security, the presence of individual fixed-effects in the equation allows us to control for individual unobserved and time-invariant heterogeneity (referring to the interpretation of the scale or personality traits). The variable $B F_{i t}$ is the treatment dummy, and is one if the worker is in a large firm and zero if the worker is in a small firm. The variable Post $t$ is a dummy for observations after January 1999. As this equation includes year fixed-effects, we do not include the variable Post $_{t}$ as it is perfectly collinear with the year dummies. Last, the coefficient of interest is that on the interaction $B F_{i t} *$ Post $_{t}: \beta_{1}$.

The coefficient $\beta_{1}$ shows how the rise in the Delalande tax affected the subjective job security of all workers in large firms by changing their probability of layoffs. We have a number of hypotheses regarding the expected sign of $\beta_{1}$. If older workers in large firms benefited from fewer layoffs, this should translate into higher subjective job security for them. But the same tax rise may have generated negative externalities on other workers. As the cost of layoffs rose for older workers, unprotected younger workers in larger firms became relatively less costly to fire with consequently lower subjective job security. As the expected effects on older and younger workers go in opposite directions, the sign of $\beta_{1}$ is ambiguous. ${ }^{7}$

We then separate the impact of the reform between older and younger workers, and estimate the following equation:

$$
\begin{array}{r}
J S_{i t}=\alpha+\beta_{3}\left(\text { BF }_{i t} * \text { Post }_{t} * \text { BornBefore 1949) }+\beta_{4}\left(\text { BF }_{i t} * \text { Post }_{t} * \text { BornAfter 1951 }\right)_{1}\right. \\
+B F_{i t}+\beta_{5} X_{i t}+\mu_{i}+\lambda_{t}+\epsilon_{i t}
\end{array}
$$

Equation (2) is the counterpart of equation (1), except that we now interact the treatment with the following dummy variables: "Born before 1949" and "Born after 1951". As such, $\beta_{3}$ in equation (2) isolates the effect of job protection on the perceived job security of older workers while $\beta_{4}$ analogously picks up any effect on younger workers.

\footnotetext{
${ }^{7} \mathrm{~A}$ large branch of the literature has already suggested that utility is relative. If subjective job security is also relative, we might also expect comparison effects here.
} 
We again emphasize that those equations assess the effect of partial protection via the probability of layoff, and do not reflect the effect of the reform on job creation and the perceived job-finding probability: workers in small firms might be subsequently hired in large firms, and vice versa.

\section{Results}

\subsection{Main Results}

The results from the difference-in-difference estimate of the baseline regression equation (1) appear in column (1) of Table 2. These suggest that the reform reduced subjective job security in the whole sample of workers. Column (2) splits the treated workers (in firms with over 50 employees) into two groups: the older ("Born before 1949"), who are protected by the Delalande tax, and the younger ("Born after 1951"). The results show that older workers benefited from the reform, while the job security of younger workers fell. The estimated coefficients for both groups are very similar at 0.11 of a standard deviation in job security. As unprotected workers constitute the large majority of the sample, the aggregate effect on the whole sample is negative (as shown in column (1) $)^{8}$.

Our assumption here is that, conditional on controls, the change in job security over time between workers in large and small firms would have been the same without the rise in the Delalande tax. This assumption can be tested by plotting the evolution of the job security regression residual on the controls: if the pattern is similar in the two groups prior to the reform, we can conclude that this assumption is reasonable. This is borne out in Figures A.3 to A.5: a clear difference in the movement over time only starts in the year the reform was announced (1998) in Figures A.3 and A.4. This gap is in favor of the control group, and suggests a negative (anticipated) effect of the reform for the whole sample, and for younger (unprotected) workers. Figure A.5 instead shows a positive effect on job security for older (protected) workers that starts the year the reform is implemented (1999).

We then account for anticipation in Table 2 by adding an interaction term indicating if the individual was in the treatment group in 1998: "Treatment x 1998". Columns (5) and (6) of Table 2 confirm that job security was lower in 1998 for the treatment group, especially

\footnotetext{
${ }^{8} 80 \%$ of treated workers are younger unprotected workers.
} 
for young unprotected workers.

\subsection{Channels}

According to Böckerman, Ilmakunnas \& Johansson (2011), perceived job security is a decreasing function of layoff rates. Following the theoretical model developed in Behaghel (2007), we expect the layoff rates of younger and older workers in large firms to react to the Delalande reform in opposite ways: the layoff probability of younger workers should rise, while that of older protected workers should fall. To check whether perceived job security mirrors the evolution in layoff rates, we calculate the layoff rates of younger and older workers in large and small firms using the French Labour Force Survey and estimate the following equation where Outcomesit stands for perceived job security and layoff rates:

$$
\text { Outcomes }_{i t}=\alpha+B F_{i t} * \lambda_{t}+B F_{i t}+\beta_{2} X_{i t}+\mu_{i}+\lambda_{t}+\epsilon_{i t}
$$

In order to capture the dynamics of the effect on both perceived job security and layoff rates, equation (3) above decomposes the treatment effect by year with 1995 as the reference period.

Figures A.1 and A.2 show the layoff rates for these two groups of workers. As expected, Figure A.1 reveals similar movements in the layoffs of younger workers in large and small firms until 1997, followed by a clear increase in large firms in 1998, the year the reform was announced. The time profile of layoff rates is thereafter similar: the negative effect of higher protection on non-protected workers came into effect as soon as the reform was announced. Figure A.2 reveals the same parallel movements before 1998 for older workers, followed by a spike in layoffs in large firms in 1998. Firms thus anticipated the higher firing costs starting in 1999. More surprisingly, the gap in layoffs between large and small firms returns to the pre-1998 level from 1999 onwards. We instead here would have expected a greater drop in layoffs in large firms in 1999. However, higher firing costs do not seem to have translated into lower layoff rates here. These results suggest greater layoff consequences for unprotected (younger) workers than for protected (older) workers.

Figures 2 and 3 show the estimated coefficients from the dynamic difference-in-difference regression equation on the subsamples of younger and older workers, with the dependent variable being a dummy for being laid off in Panel A and perceived job security in Panel B. 
The results in Panel A confirm the previous conclusions in both figures, with positive and significant coefficients for younger workers from 1998 onwards, while only the 1998 coefficient is significantly positive for older workers. The insignificant coefficients for years before 1998 are in line with Figures A.1 and A.2 and confirm that the time profile of layoffs in small and large firms was similar prior to the rise in the Delalande tax. The significant coefficients on years after the reform can therefore reasonably be interpreted as having been caused by the reform.

If perceived job security is a decreasing function of layoff rates, we should then expect coefficients displayed in Panel B of Figures 2 and 3 to mirror the coefficients in Panel A. This is confirmed for younger workers: as soon as their layoff rates significantly increases at the time of the reform's announcement, their perceived job security starts to fall. But Figure 3 displays a different pattern. We do not identify significant variations in layoff rates, except a spike in 1998 when the reform was announced. Then, even if there is no significant decreases in layoff rates of older workers, their perceived job security rises from 1999 onwards. This result implies that layoff rates may definitely affect perceived job security but this is not the only channel.

We have so far considered that perceived job security only depends on the absolute level of employment protection as measured by layoff rates. However, we know that subjective assessments of job quality depends on relative job characteristics. Clark \& Oswald (1996) demonstrate for instance that job satisfaction is positively correlated with income but negatively correlated with the income in the reference group. Following the same reasoning, perceived job security may also depends on the relative level of employment protection. Even if their actual layoff rate was not affected by the reform of the Delalande tax, older workers in large firms may feel more protected because younger workers are now more likely to be laid of: older workers feel relatively more protected. 


\section{Robustness Checks and Heterogeneity}

\subsection{Robustness Checks}

\subsubsection{Ruling out confounding shocks}

The estimated coefficients in Table 2 show how job security changed for the treated and control groups after 1998. To ensure that these only reflect the change in the Delalande tax, we need to be sure to have ruled out any effect from other confounding policies or macroeconomic events.

One issues regarding our identification assumption lies in the French reform of the mandatory weekly working time. In 1998, the French Ministry of Labour announced a reduction in the standard workweek from 39 to 35 hours in companies with more than 20 employees. This may have affected worker's perceived job security in those firms. To ensure that our main result of lower job security following the Delalande tax is not picking up this other reform, we re-run the baseline regression excluding workers in firms with under 20 employees. These results appear in column (1) of Table 3, and are consistent with the baseline results. The positive impact on the perceived job security of older workers is less significant here due to the smaller sample size.

Last, we would like to check that our results reflect the French reforms, rather than some broader macro-economic trend. We do so by re-running our baseline regressions on similar samples of workers in neighbouring countries, as the ECHP is harmonized across European countries. Data limitations restrict this comparison to Spain and Italy. ${ }^{9}$ The difference-indifference estimates in these countries appear in columns (2) and (3) of Table 3 and are not significantly different from zero. Macroeconomic trends do not seem to be behind our results.

\subsubsection{Using alternative control groups}

Our approach above was to use workers in small firms as the control group to establish the impact of the reform on workers in large firms. We also check our findings using public-sector workers as the controls. As they were not covered by the Delalande tax, we assume that their perceived job security was not affected by it.

\footnotetext{
${ }^{9}$ Perceived job security is not measured after 1997 in Germany, and the information in the last waves of the ECHP in Belgium is insufficient to accurately differentiate the public and private sectors.
} 
Column (4) of Table 3 shows the results. The new estimates are very similar to the baseline estimates. Figures A.6 and A.7 show the time-varying regression coefficients using public-sector workers as the control group. ${ }^{10}$

\subsubsection{Using different estimation methods}

We now check whether our results depend on the estimation method. In the baseline regressions, we treated job security as cardinal. As job security is measured on an ordinal scale, ordered response models may be more appropriate. However, Ferrer-i Carbonell \& Frijters (2004) conclude that treating subjective wellbeing scores as ordinal or cardinal makes little difference in panel regressions. We first re-estimate our main regression on pooled data with an ordered logit, as shown in column (5) of Table 3. Allowing job security to be ordinal does not change our conclusions. There is no clear consensus in the literature regarding efficient fixed effect estimators in ordered logits. In a recent paper, Baetschmann, Staub \& Winkelmann (2015) compare the performance of various estimators for the fixed effects ordered logit model in a Monte Carlo study, and recommend the "Blow-up and Cluster" (or BUC) estimator. Column (6) of Table 3 reports our main regression results re-estimated using the BUC estimator. ${ }^{11}$ The results are again qualitatively similar. ${ }^{12}$

We also check how the use of individual fixed effects affects our results: the baseline results without fixed affects appear in Table 3. The conclusions are qualitatively unchanged, even if the coefficients do differ slightly from those in the baseline estimates. The FE and OLS estimates may differ for two main reasons. First, fixed-effects models introduce attenuation bias in the case of measurement error, so that OLS estimates are always higher than their FE counterparts in absolute terms. This is not the case here, as the pooled OLS coefficients are smaller than the FE estimates in absolute terms. Selection also plays a role: the OLS estimates are biased if the treatment is correlated with individual unobserved time-invariant characteristics. Comparing the results in column (7) of Table 3 to the baseline estimates (and those from the ordered logit to the BUC estimates with a fixed effect) suggests that treated

\footnotetext{
${ }^{10}$ We also used both workers from small firms and in the public sector as a control group. This led to very similar results, which are available on request.

${ }^{11}$ The difference in sample size in Column (6) is due to the use of the BUC estimator, which artificially increases the number of individual observations.

${ }^{12}$ The coefficients in column (5) and (6) are ordered log-odds estimates, and cannot be directly compared to those from linear models. However, the signs and significance levels are directly comparable.
} 
individuals were those with somewhat lower job security to start with.

\subsection{Heterogeneity}

The D-i-D estimates in Table 2 show the average "treatment" effect for workers in large firms. Tables 4 to 6 ask whether these effects differ across groups; column (1) in both Tables reproduces the baseline results. As it is known that the determinants of subjective variables differ by gender (Fugl-Meyer, Melin \& Fugl-Meyer (2002)), column (2) of Table 4 first interacts our treatment estimates with a female dummy, and finds no significant sex difference.

We then look at education in Table 5: older workers with lower education may be more concerned about employment protection if it is more difficult for them to find a new job. Education in the ECHP is measured by the highest diploma obtained using the International Standard Classification of Education - 1976 (or ISCED): "High education" for tertiary education, "Intermediate education" for upper-secondary education, and "Low education" for lower levels of education. Column (2) of Table 5 shows the results with education interactions. The fall in perceived job security for the younger is independent of education, but the average positive coefficient for older workers is mainly driven by those with intermediate and lower education. This result supports that workers with lower education benefit more from employment protection.

As the Delalande tax was stated in months of gross wage, the higher the monthly wage, the more layoffs cost. For older workers, higher monthly wages translated into more protection. On the contrary, higher wages for younger workers may have provided incentives for employers to lay them off before they become protected by the Delalande tax. We hence interact the treatment dummy with a dummy indicating whether workers earned more than the annual median income. Column (2) of Table 6 shows the results. Although the pattern of the results is in line with our predictions (greater job security rise for higher-income older workers; greater job security fall for higher-income younger workers), none of the income interaction terms turn out to be significant. ${ }^{13}$

The treatment effect might also differ by age: the closer to 50 the worker is, the greater the probability to become more costly to fire in the near future. This might translate into a

\footnotetext{
${ }^{13}$ The negative impact among younger workers is higher for those with relatively high wages but also for those with lower education, which might seem counterintuitive. However, the correlation between lower education and income is only 0.31 in our sample. This relatively small correlation means that education and wage can be considered as distinct sources of heterogeneity.
} 
larger tax effect for workers who are closer to 50 than for younger workers. We thus interact the treatment estimate with the following age dummies (age being measured at the time of the reform): 18 to $30,{ }^{14} 30$ to 35,35 to 40,40 to 45,45 to 48,50 to 55 , and over 55 . Figure 4 depicts the results. All the estimated coefficients up to age 45 are negative but are not very significant. It is between 45 and 48 years old that the rise in the Delalande tax has its largest negative effect on perceived job security. The impact is very similar for workers aged 50 to 55 , and over 55 to the right of the Figure. ${ }^{15}$

\section{Conclusion}

This paper asked how partial employment protection might affect worker's subjective job security by changing their perceived probability of layoff. We find that the increase in the French Delalande tax, a firing tax restricted to older workers, translates into greater subjective job security for older workers. However, this exogenous rise in older workers' employment protection also reduced the relative firing cost of younger workers, leading to lower job security for this group. As uncovered workers constitute the large majority of the sample, the aggregate effect on the whole sample of workers is negative. As perceived job security falls with the probability of job loss, the lower perceived job security of younger workers is perfectly consistent with the increase in their layoff rate, compared to younger workers in smaller firms. But the increase in perceived job security of older workers in large firms is not mirrored in their layoff rate. This may reflect that perceived job security not only depends on absolute employment protection but also on its relative level. With the increase in the Delalande tax, older workers may have felt more protected as the layoff rate of their younger colleagues increased.

We confirm the predictions of Behaghel (2007) regarding layoffs and the subjective job security of younger workers. However, we should also emphasize that we have not explored his predictions regarding job creation, which might affect both workers and the unemployed. In particular, our analysis did not allow us to see whether employment protection reduces the probability that the unemployed find work. The investigation of the relation between partial employment-protection reforms and job finding, and how this affects worker's subjective job

\footnotetext{
${ }^{14}$ This age interval is larger than the other intervals as the age distribution in our sample is left-skewed.

${ }^{15}$ The estimates and standard errors appear in Table A.3 in the Appendix.
} 
security, is a promising subject for future research.

In terms of the net welfare impact, we should also stress that the average negative effect in terms of perceived job security does not automatically mean that the Delalande tax reform had a negative net welfare impact. Job security may be more important for the wellbeing of older workers than younger workers, producing a greater weight on the job security of the former, and the potential for net welfare gains. 


\section{References}

Akerlof, George A, Andrew K Rose, Janet L Yellen, Laurence Ball, and Robert E Hall. 1988. "Job switching and job satisfaction in the US labor market." Brookings Papers on Economic Activity, 1988(2): 495-594.

Autor, David H, William R Kerr, and Adriana D Kugler. 2007. "Does employment protection reduce productivity? Evidence from US states." The Economic Journal, 117(521): F189-F217.

Baetschmann, Gregori, Kevin E Staub, and Rainer Winkelmann. 2015. "Consistent estimation of the fixed effects ordered logit model." Journal of the Royal Statistical Society: Series A (Statistics in Society), 178(3): 685-703.

Behaghel, Luc. 2007. "La protection de l'emploi des travailleurs âgés en France: une évaluation ex ante de la contribution Delalande." Annales d'Economie et de Statistique, $41-80$.

Behaghel, Luc, Bruno Crépon, and Béatrice Sédillot. 2008. "The perverse effects of partial employment protection reform: The case of French older workers." Journal of Public Economics, 92(3): 696-721.

Blanchard, Olivier, and Augustin Landier. 2002. "The perverse effects of partial labour market reform: fixed-term contracts in France." The Economic Journal, 112(480): F214F244.

Böckerman, Petri. 2004. "Perception of job instability in Europe." Social Indicators Research, 67(3): 283-314.

Böckerman, Petri, Pekka Ilmakunnas, and Edvard Johansson. 2011. "Job security and employee well-being: Evidence from matched survey and register data." Labour Economics, 18(4): 547-554.

Boeri, Tito, and Juan F Jimeno. 2005. "The effects of employment protection: Learning from variable enforcement." European Economic Review, 49(8): 2057-2077.

Cahuc, Pierre, and Fabien Postel-Vinay. 2002. "Temporary jobs, employment protection and labor market performance." Labour Economics, 9(1): 63-91.

Clark, Andrew. 2001. "What really matters in a job? Hedonic measurement using quit data." Labour Economics, 8(2): 223-242.

Clark, Andrew, and Fabien Postel-Vinay. 2009. "Job security and job protection." Oxford Economic Papers, 61(2): 207-239. 
Clark, Andrew E, and Andrew J Oswald. 1996. "Satisfaction and comparison income." Journal of Public Economics, 61(3): 359-381.

Clark, Andrew, Yannis Georgellis, and Peter Sanfey. 1998. "Job satisfaction, wage changes and quits: Evidence from Germany." Research in Labor Economics, 17.

Dolado, Juan J, Carlos García-Serrano, and Juan F Jimeno. 2002. "Drawing lessons from the boom of temporary jobs in Spain." The Economic Journal, 112(480): F270-F295.

Ferrer-i Carbonell, Ada, and Paul Frijters. 2004. "How important is methodology for the estimates of the determinants of happiness?" The Economic Journal, 114(497): 641659 .

Freeman, RB. 1978. "Job Satisfaction as an Economic Variable." The American Economic Review, 68(2): 135-141.

Fugl-Meyer, Axel R, Roland Melin, and Kerstin S Fugl-Meyer. 2002. "Life satisfaction in 18-to 64-year-old Swedes: in relation to gender, age, partner and immigrant status." Journal of Rehabilitation Medicine, 34(5): 239-246.

Gómez-Salvador, Ramón, Julián Messina, and Giovanna Vallanti. 2004. "Gross job flows and institutions in Europe." Labour Economics, 11(4): 469-485.

Harter, James K, Frank L Schmidt, and Theodore L Hayes. 2002. "Business-unit-level relationship between employee satisfaction, employee engagement, and business outcomes: A meta-analysis." Journal of Applied Psychology, 87(2): 268.

Kugler, Adriana, and Giovanni Pica. 2008. "Effects of employment protection on worker and job flows: Evidence from the 1990 Italian reform." Labour Economics, 15(1): 78-95.

Kugler, Adriana, Juan F Jimeno, Virginia Hernanz, et al. 2002. "Employment Consequences of Restrictive Permanent Contracts: Evidence from Spanish Labor Market Reforms." Institute for the Study of Labor (IZA).

Mortensen, Dale T, and Christopher A Pissarides. 1994. "Job creation and job destruction in the theory of unemployment." The Review of Economic Studies, 61(3): 397-415.

Mortensen, Dale T, and Christopher A Pissarides. 1999. "New developments in models of search in the labor market." Handbook of labor economics, 3: 2567-2627.

Pissarides, Christopher A. 2000. Equilibrium unemployment theory. MIT press.

Postel-Vinay, Fabien, and Anne Saint-Martin. 2004. "Comment les salariés perçoiventils la protection de l'emploi?" Economie et Statistique, 372(1): 41-59. 


\section{Figures and Tables}

Figure 1: The Distribution of Satisfaction with Job Security

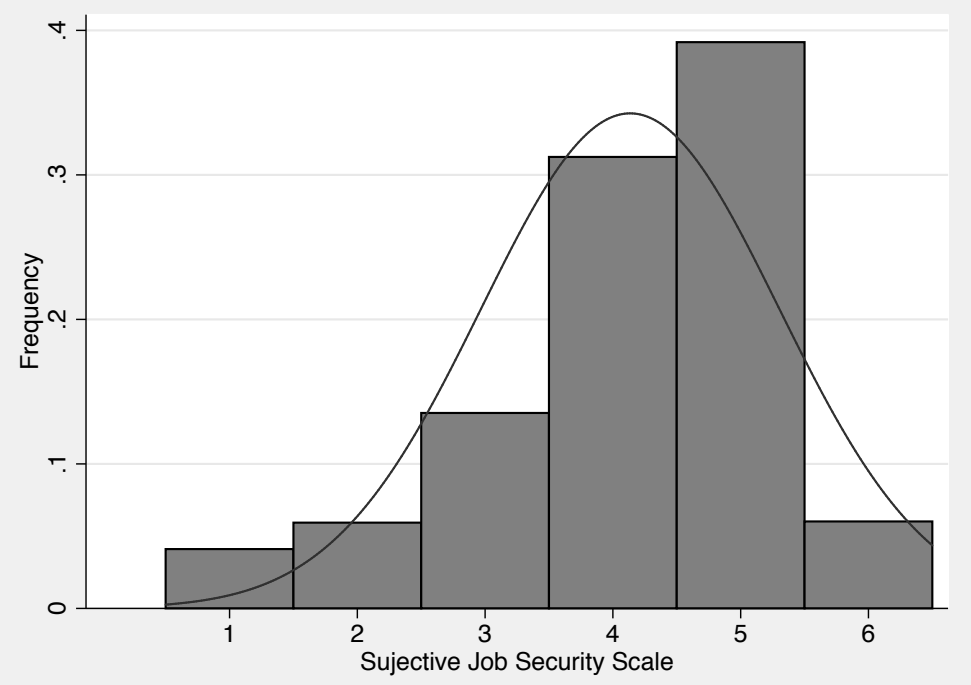

Source: ECHP 
Figure 2: Layoff and Perceived Job Security Regression Coefficients Over Time - Younger Workers

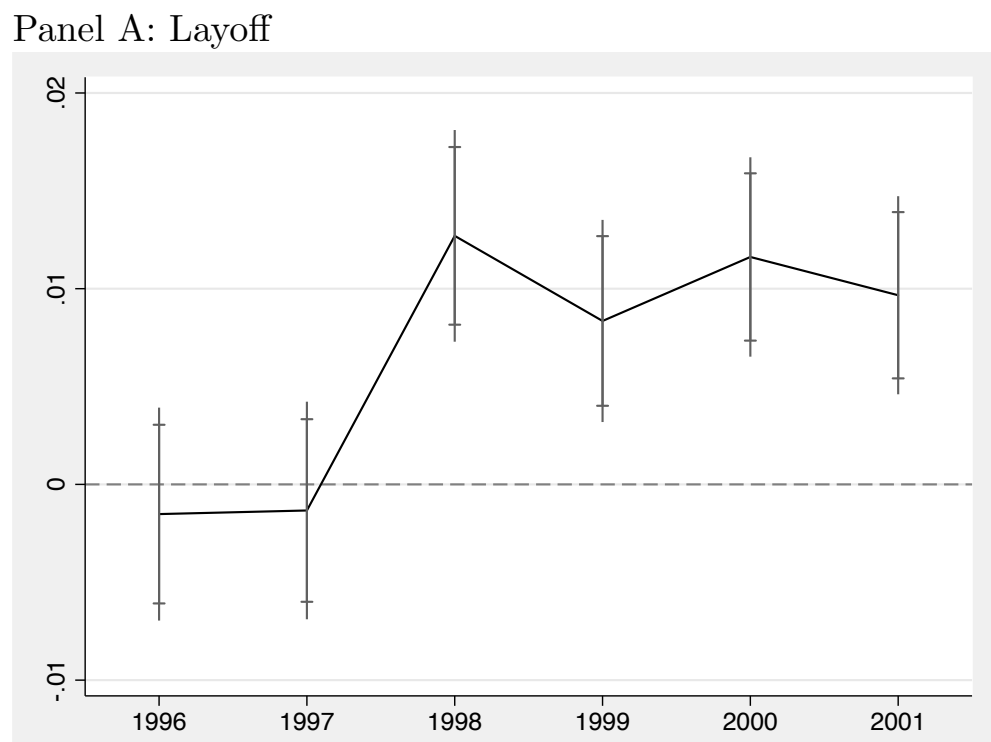

Panel B: Perceived Job Security

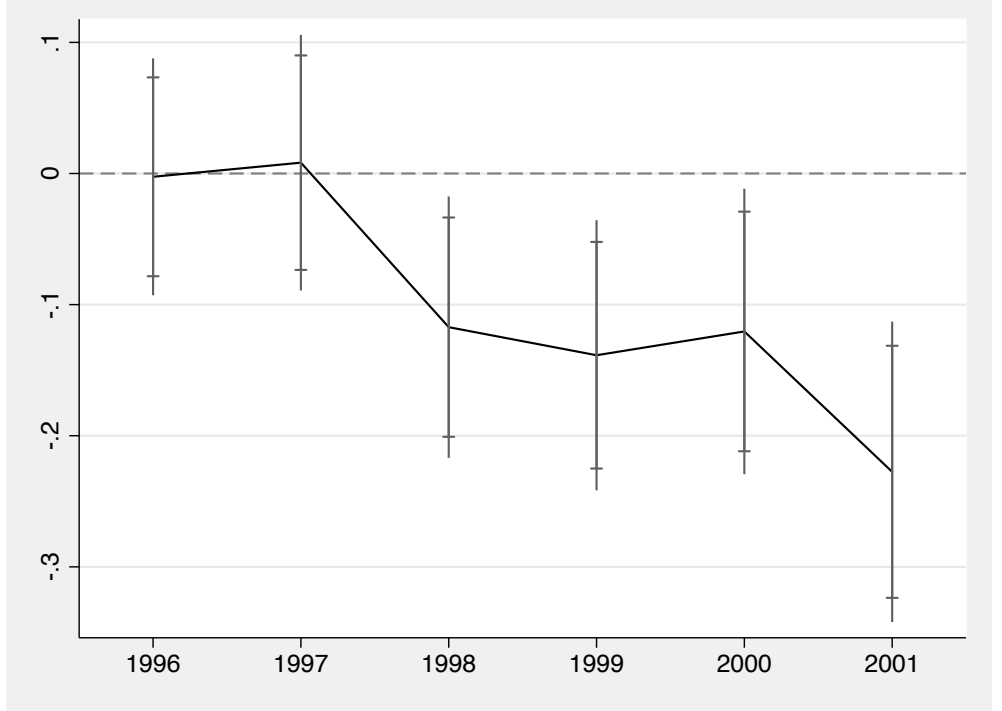

Source: Results in Panel A come from the French Labour Survey (152 795 observations). The controls in Panel A are gender, education level, age, age squared and dummies for children under 3,6 18, region and year. Results in Panel B come from the ECHP. The controls include an individual FE, age squared and dummies for marital status, children in the household, region and year. The sample is restricted to workers born before December 1951 in both panels. The confidence intervals are at the $5 \%$ and $10 \%$ levels. The standard errors are clustered at the individual level. 
Figure 3: Layoff and Perceived Job Security Regression Coefficients Over Time - Older Workers

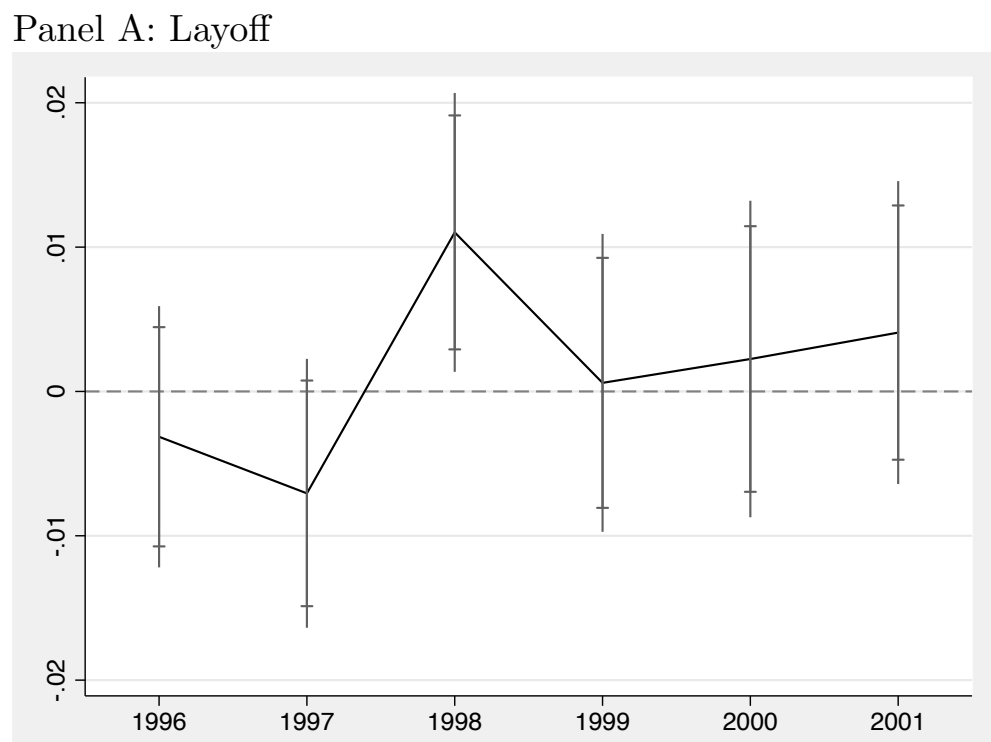

Panel B: Perceived Job Security

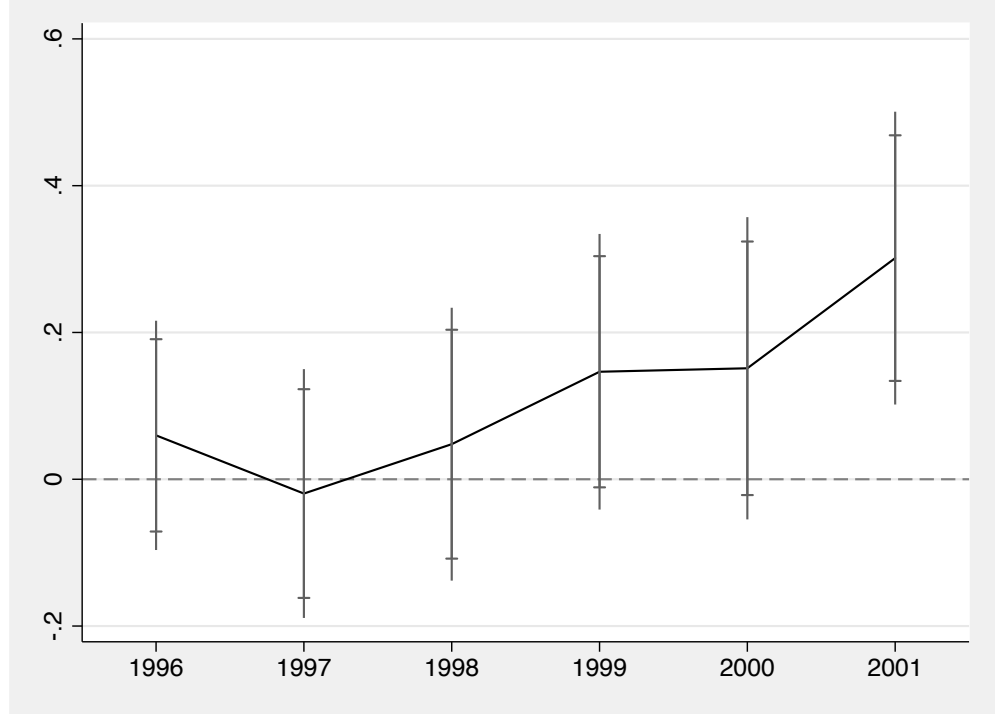

Source: Results in Panel A come from the French Labour Survey (55 159 observations). The controls in Panel A are gender, education level, age, age squared and dummies for children under 3,6 18, region and year. Results in Panel B come from the ECHP. The controls include an individual FE, age squared and dummies for marital status, children in the household, region and year. The sample is restricted to workers born before September 1949 in both panels. The confidence intervals are at the $5 \%$ and $10 \%$ levels. The standard errors are clustered at the individual level. 
Figure 4: Heterogeneity - Age at the time of the reform

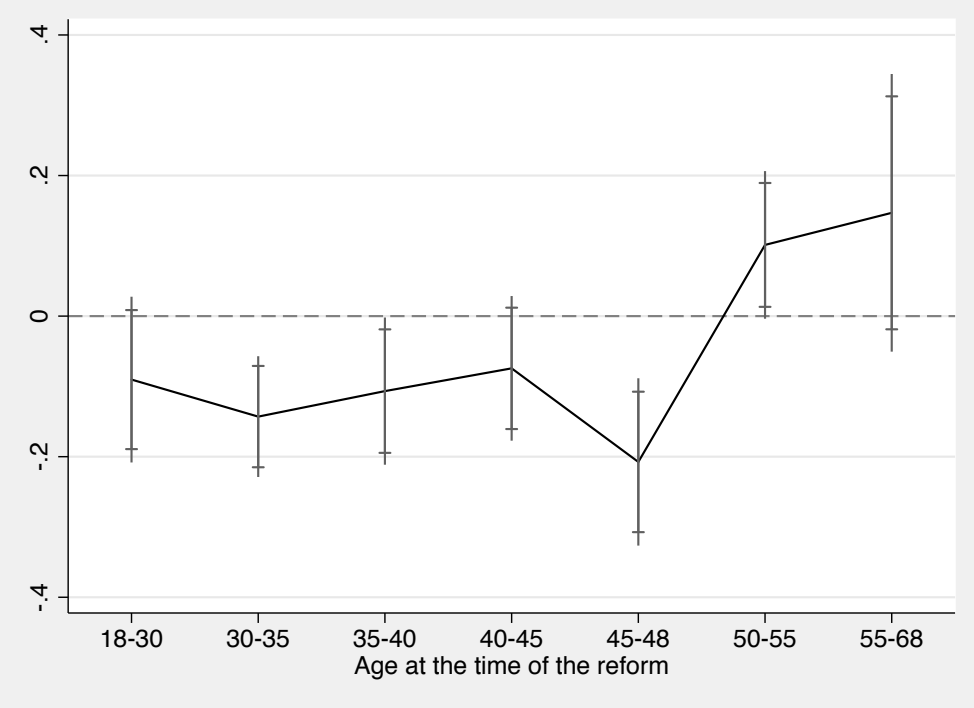

Confidence intervals are at the $5 \%$ and $10 \%$ levels. Standard errors are clustered at the individual level. Controls include an individual FE, age squared, and dummies for marital status, children in the household, region, and year. 
Table 1: The Delalande Tax scheme

\begin{tabular}{lccccccccccc}
\hline & & \multicolumn{1}{c}{ Worker's age } \\
\cline { 3 - 11 } & & 50 & 51 & 52 & 53 & 54 & 55 & $56-57$ & 58 & 59 \\
\hline July 1987-June 1992 & All firm sizes & & & & & & 3 & 3 & 3 & 3 \\
& & & & & & & & & \\
July 1992 - Dec. 1992 & More than 20 employees & 1 & 1 & 2 & 2 & 4 & 5 & 6 & 6 & 6 \\
& Less than 20 employees & 0.5 & 0.5 & 1 & 1 & 2 & 2.5 & 3 & 3 & 3 \\
Jan 1993-Dec 1998 & All firm sizes & 1 & 1 & 2 & 2 & 4 & 5 & 6 & 6 & 6 \\
& More than 50 employees & 2 & 3 & 5 & 6 & 8 & 10 & 12 & 10 & 8 \\
After January 1999 & Less than 50 employees & 1 & 1 & 2 & 2 & 4 & 5 & 6 & 6 & 6 \\
\hline
\end{tabular}

Source: Legislative texts

Note: For each age group, the table displays the tax due by the firm to the unemployment insurance system if it lays the worker off. The tax is a function of previous wages, and is stated in months of gross wage. 
Table 2: The Rise in the Delalande Tax -

Panel Results

\begin{tabular}{|c|c|c|c|c|}
\hline & \multicolumn{4}{|c|}{ Perceived Job Security } \\
\hline & \multicolumn{2}{|c|}{ Baseline Results } & \multicolumn{2}{|c|}{$\begin{array}{c}\text { Accounting for } \\
\text { Anticipation in } \\
1998\end{array}$} \\
\hline & (1) & $(2)$ & $(3)$ & $(4)$ \\
\hline Treatment*Post & $\begin{array}{c}-0.07^{* *} \\
(0.03)\end{array}$ & & $\begin{array}{c}-0.10^{* * *} \\
(0.03)\end{array}$ & \\
\hline Treatment*Post*Born before 1949 & & $\begin{array}{l}0.11^{* *} \\
(0.05)\end{array}$ & & $\begin{array}{l}0.11^{* *} \\
(0.06)\end{array}$ \\
\hline Treatment*Post*Born after 1951 & & $\begin{array}{c}-0.11^{* * *} \\
(0.03)\end{array}$ & & $\begin{array}{c}-0.15^{* * *} \\
(0.03)\end{array}$ \\
\hline Treatment*1998 & & & $\begin{array}{c}-0.09^{* *} \\
(0.03)\end{array}$ & \\
\hline Treatment*1998*Born before 1949 & & & & $\begin{array}{l}-0.01 \\
(0.06)\end{array}$ \\
\hline Treatment*1998*Born after 1951 & & & & $\begin{array}{c}-0.11^{* * *} \\
(0.04)\end{array}$ \\
\hline Observations & 14110 & 14110 & 14110 & 14110 \\
\hline Individuals & 3003 & 3003 & 3003 & 3003 \\
\hline
\end{tabular}




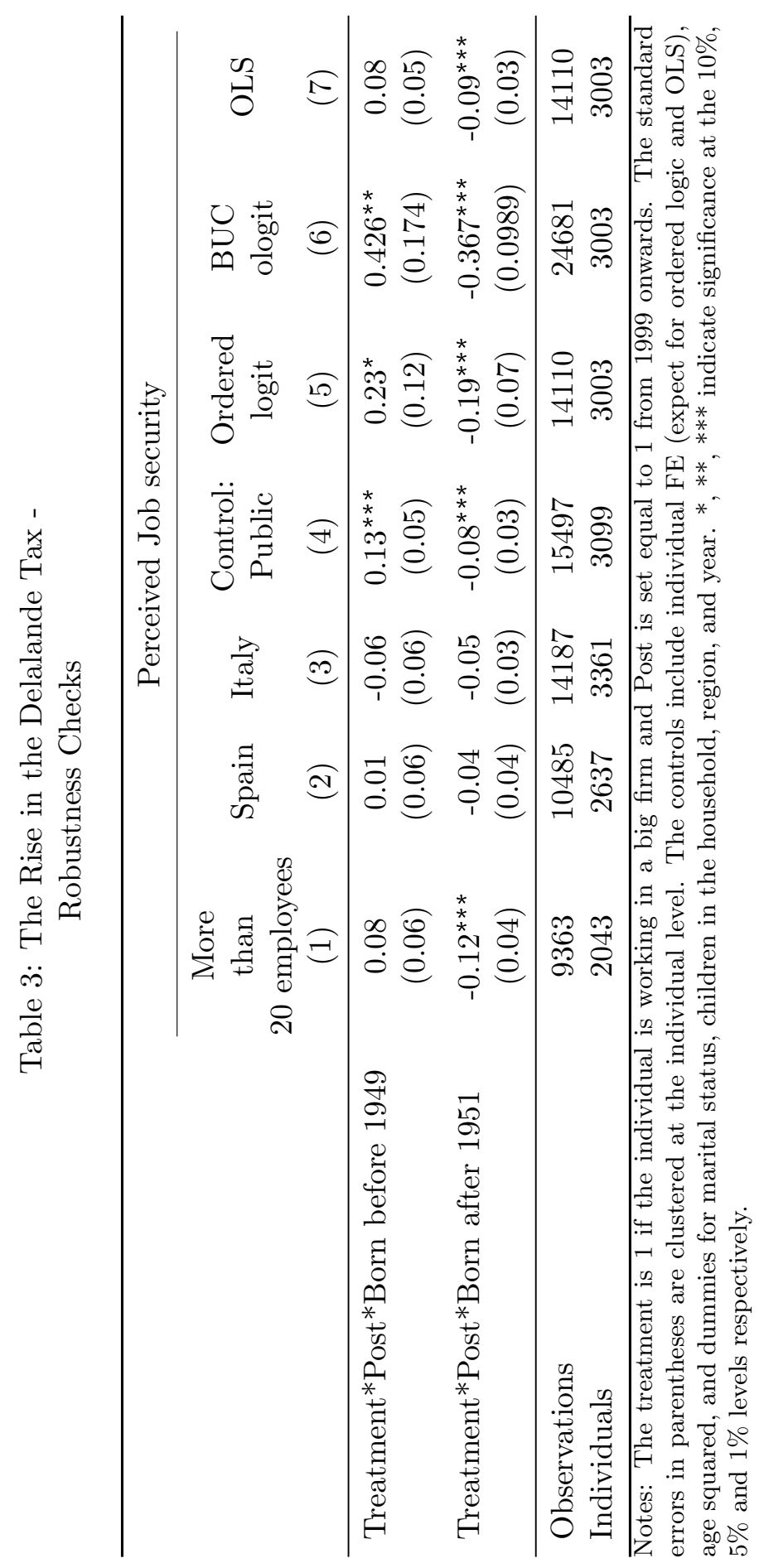


Table 4: The Rise in the Delalande Tax -

Panel Results by Gender

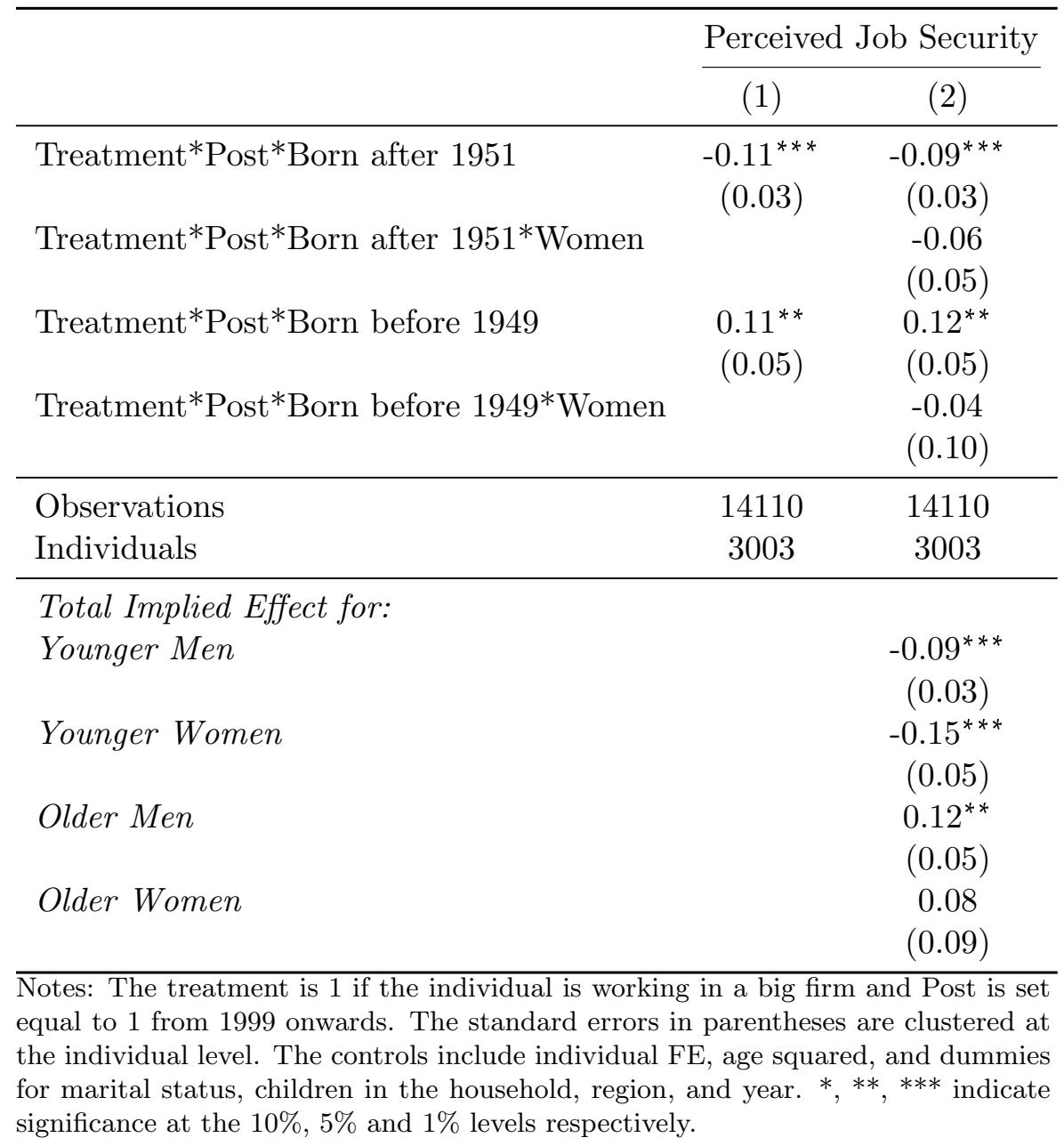


Table 5: The Rise in the Delalande Tax -

Panel Results by Education

Perceived Job Security

(1) (2)

Treatment*Post*Born before 1949

$0.11^{* *} \quad 0.14^{* * *}$

Treatment*Post*Born before 1949*High Education

$-0.16$

Treatment*Post*Born before $1949 *$ Interm. Education

Treatment*Post*Born after 1951

$(0.15)$

$-0.11^{* * *}$

Treatment*Post*Born after 1951*High Education

$(0.03) \quad(0.04)$

$-0.01$

$(0.05)$

Treatment*Post*Born after $1951 *$ Interm. Education

$-0.02$

$(0.07)$

\begin{tabular}{lcc}
\hline Observations & 14110 & 14110 \\
Individuals & 3003 & 3003 \\
\hline
\end{tabular}

Total Implied Effect for Young:

Workers with Low level of Education $\quad-0.11^{* * *}$

Workers with Intermediate level of Education $\quad-0.12^{* * *}$

Workers with High level of Education $-0.12^{*}$

Total Implied Effect for Older:

Workers with Low level of Education $0.14^{* * *}$

0.18

Workers with High level of Education $\quad-0.02$

$(0.10)$

Notes: The treatment is 1 if the individual is working in a big firm and Post is set equal to 1 from 1999 onwards. The standard errors in parentheses are clustered at the individual level. The controls include individual FE, age squared, and dummies for marital status, children in the household, region, and year. "Low education": less than lower secondary education; "Intermediate education": upper secondary education; "High education": higher education. *, $* *, * * *$ indicate significance at the $10 \%, 5 \%$ and $1 \%$ levels respectively. 
Table 6: The Rise in the Delalande Tax -

Panel Results by Income

\begin{tabular}{lcc}
\hline & \multicolumn{2}{c}{ Perceived Job Security } \\
\cline { 2 - 3 } & $(1)$ & $(2)$ \\
\hline Treatment*Post*Born before 1949 & $0.11^{* *}$ & 0.06 \\
& $(0.05)$ & $(0.08)$ \\
Treatment*Post*Born before 1949*High Income & & 0.07 \\
& & $(0.08)$ \\
Treatment*Post*Born after 1951 & $-0.11^{* * *}$ & $-0.09^{*}$ \\
& $(0.03)$ & $(0.04)$ \\
Treatment*Post*Born after 1951*High Income & & -0.04 \\
& & $(0.04)$ \\
\hline Observations & 14110 & 14110 \\
Individuals & 3003 & 3003 \\
\hline
\end{tabular}

Total Implied Effect for:

Older Workers with Low Income $\quad 0.06$

Older Workers with High Income

$(0.05)$

Young Workers with Low Income $-0.09^{*}$

Young Workers with High Income $\quad-0.13^{* * *}$

$(0.03)$

Notes: The treatment is 1 if the individual is working in a big firm and Post is set equal to 1 from 1999 onwards. The standard errors in parentheses are clustered at the individual level. The controls include individual FE, age squared, and dummies for marital status, children in the household, region, and year. "High Income" is a dummy for monthly labour income being over the annual median labour income. *, **, *** indicate significance at the $10 \%, 5 \%$ and $1 \%$ levels respectively. 


\section{Appendix}

Table A.1: Descriptive Statistics -

Whole Sample

\begin{tabular}{|c|c|c|}
\hline & Mean & S.D. \\
\hline \multicolumn{3}{|l|}{ Dependent variable: } \\
\hline Subjective Job Security (1-6) & 4.14 & 1.16 \\
\hline \multicolumn{3}{|l|}{ Socio-Demographics Variables: } \\
\hline Female (in \%) & 0.39 & 0.49 \\
\hline Age & 38.29 & 9.37 \\
\hline \multicolumn{3}{|l|}{ Marital Status: } \\
\hline Married (in \%) & 0.63 & 0.48 \\
\hline Separated (in \%) & 0.01 & 0.08 \\
\hline Divorced (in \%) & 0.06 & 0.24 \\
\hline Widowed (in \%) & 0.01 & 0.11 \\
\hline Never Married (in \%) & 0.29 & 0.45 \\
\hline \multicolumn{3}{|l|}{ Presence of Children in the Household: } \\
\hline Children under 12 in the household (in \%) & 0.45 & 0.50 \\
\hline Children between 12 and 15 in the household (in \%) & 0.09 & 0.28 \\
\hline \multicolumn{3}{|l|}{ Level of Education: } \\
\hline Low Education (in \%) & 0.26 & 0.44 \\
\hline Intermediate Education (in \%) & 0.33 & 0.47 \\
\hline High Education (in \%) & 0.42 & 0.49 \\
\hline \multicolumn{3}{|l|}{ labour Market Outcomes: } \\
\hline Net Monthly labour Income (in Francs) & 9620.15 & 6142.77 \\
\hline Weekly Working Hours & 39.87 & 8.32 \\
\hline Observations & 14110 & \\
\hline
\end{tabular}


Table A.2: Descriptive Statistics -

By Treatment Status

\begin{tabular}{|c|c|c|c|c|}
\hline & \multicolumn{2}{|c|}{ Control } & \multicolumn{2}{|c|}{ Treatment } \\
\hline & Mean & S.D. & Mean & S.D. \\
\hline \multicolumn{5}{|l|}{ Dependent variable: } \\
\hline Subjective Job Security (1-6) & 4.13 & 1.18 & 4.14 & 1.14 \\
\hline \multicolumn{5}{|l|}{ Socio-Demographics Variables: } \\
\hline Female (in \%) & 0.42 & 0.49 & 0.35 & 0.48 \\
\hline Age & 37.48 & 9.38 & 39.12 & 9.29 \\
\hline \multicolumn{5}{|l|}{ Marital Status: } \\
\hline Married (in \%) & 0.60 & 0.49 & 0.66 & 0.47 \\
\hline Separated (in \%) & 0.01 & 0.08 & 0.01 & 0.09 \\
\hline Divorced (in \%) & 0.06 & 0.24 & 0.06 & 0.23 \\
\hline Widowed (in \%) & 0.01 & 0.11 & 0.01 & 0.11 \\
\hline Never Married (in \%) & 0.32 & 0.47 & 0.26 & 0.44 \\
\hline \multicolumn{5}{|l|}{ Presence of Children in the Household: } \\
\hline Children under 12 in the household (in \%) & 0.47 & 0.50 & 0.43 & 0.50 \\
\hline Children between 12 and 15 in the household (in \%) & 0.09 & 0.28 & 0.09 & 0.28 \\
\hline \multicolumn{5}{|l|}{ Level of Education: } \\
\hline Low Education (in \%) & 0.23 & 0.42 & 0.29 & 0.45 \\
\hline Intermediate Education (in \%) & 0.33 & 0.47 & 0.32 & 0.47 \\
\hline High Education (in \%) & 0.44 & 0.50 & 0.39 & 0.49 \\
\hline \multicolumn{5}{|l|}{ labour Market Outcomes: } \\
\hline Net Monthly labour Income (in Francs) & 8471.97 & 5279.57 & 10805.02 & 6719.32 \\
\hline Weekly Working Hours & 39.82 & 9.26 & 39.91 & 7.23 \\
\hline Observations & 7166 & & 6944 & \\
\hline
\end{tabular}

Note: "Low education" corresponds to a level of education lower than secondary education, "Intermediate education" to upper secondary education and "High education" to higher levels of education. 
Table A.3: Heterogeneity - Age at the Time of the Reform

\begin{tabular}{lc}
\hline & Perceived Job Security \\
\hline Age at the time of the reform: & -0.09 \\
$18-30$ & $(0.06)$ \\
& $-0.14^{* * *}$ \\
$30-35$ & $(0.04)$ \\
& $-0.11^{* *}$ \\
$35-40$ & $(0.05)$ \\
& -0.07 \\
$40-45$ & $(0.05)$ \\
& $-0.21^{* * *}$ \\
$45-48$ & $(0.06)$ \\
& $0.10^{*}$ \\
$50-55$ & $(0.05)$ \\
& 0.15 \\
$55-68$ & $(0.10)$ \\
& 14110 \\
Observations & 3003 \\
\hline
\end{tabular}

Note: Treatment is 1 if the individual is working in a large firm and Post equals 1 from 1999 onwards. The standard errors in parentheses are clustered at the individual level. The controls include an individual $\mathrm{FE}$, age squared, and dummies for marital status, children in the household, region, and year. *, **, *** indicate significance at the $10 \%, 5 \%$ and $1 \%$ levels respectively. 
Figure A.1: Layoff Rates - Younger Workers

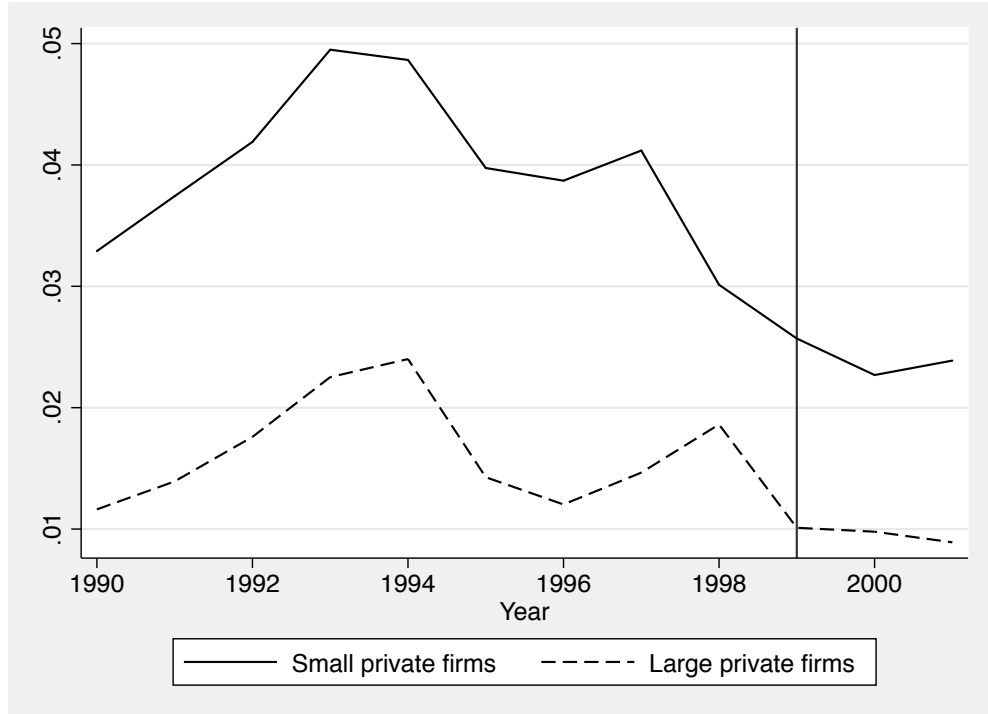

Source: French Labour Survey. The sample is restricted to workers born after December 1951.

Figure A.2: Layoff Rates - Older Workers

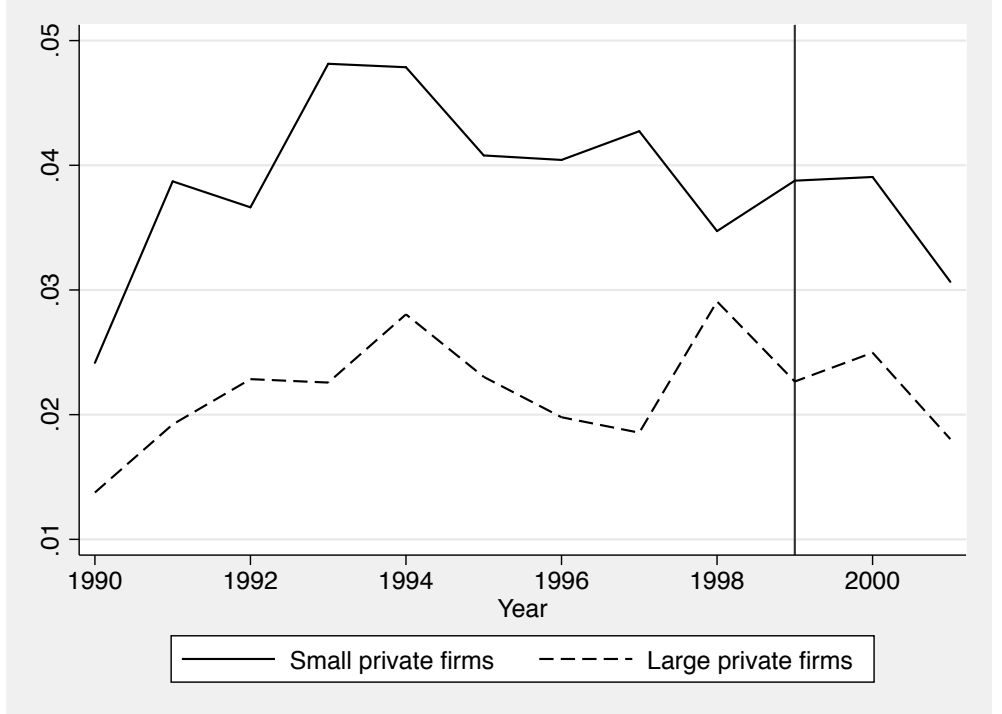

Source: French Labour Survey. The sample is restricted to workers born before September 1949. 
Figure A.3: Job Security Residuals - Whole Sample

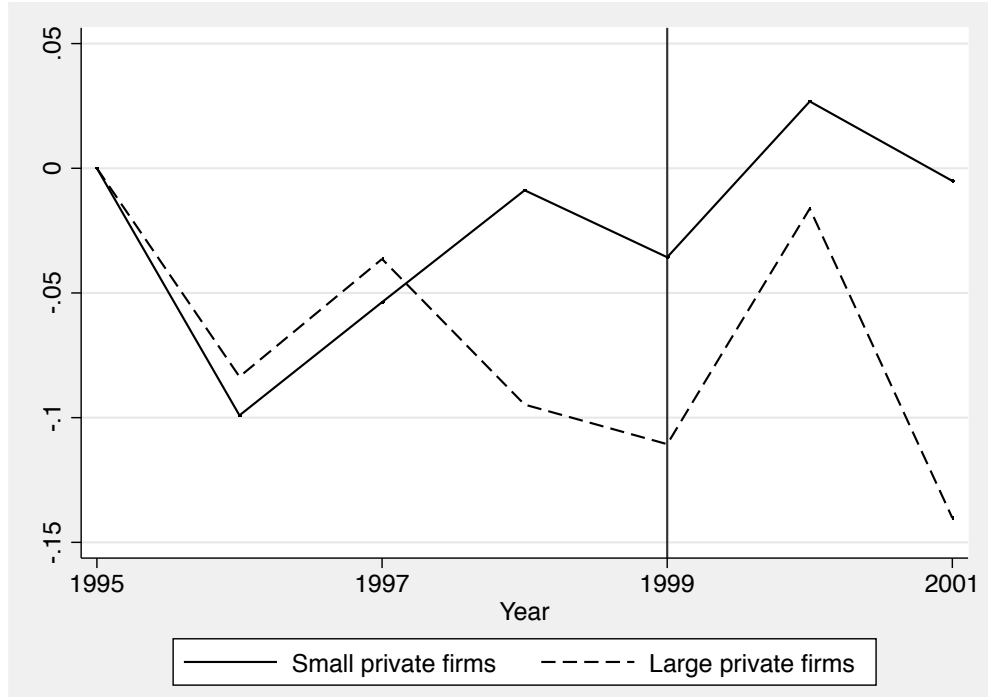

Source: ECHP. The residuals are from the regression of job security on an individual FE, age squared, and dummies for marital status, children in the household and region.

Figure A.4: Job Security Residuals - Younger Workers

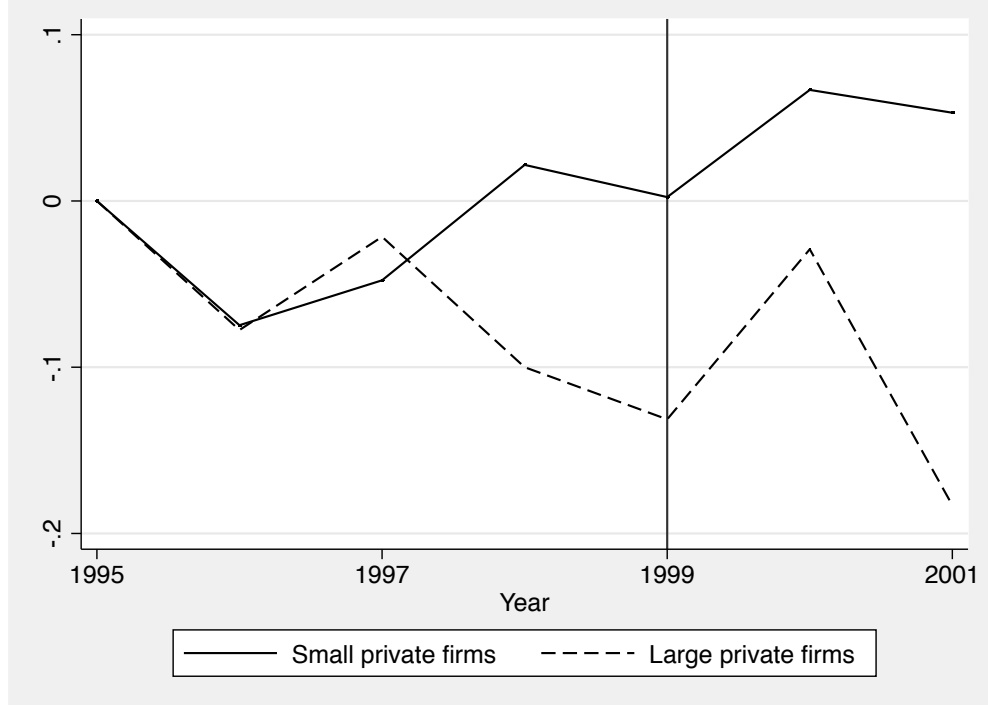

Source: ECHP. The residuals are from the regression of job security on an individual FE, age squared, and dummies for marital status, children in the household and region. The sample is restricted to workers born after December 1951. 
Figure A.5: Job Security Residuals - Older Workers

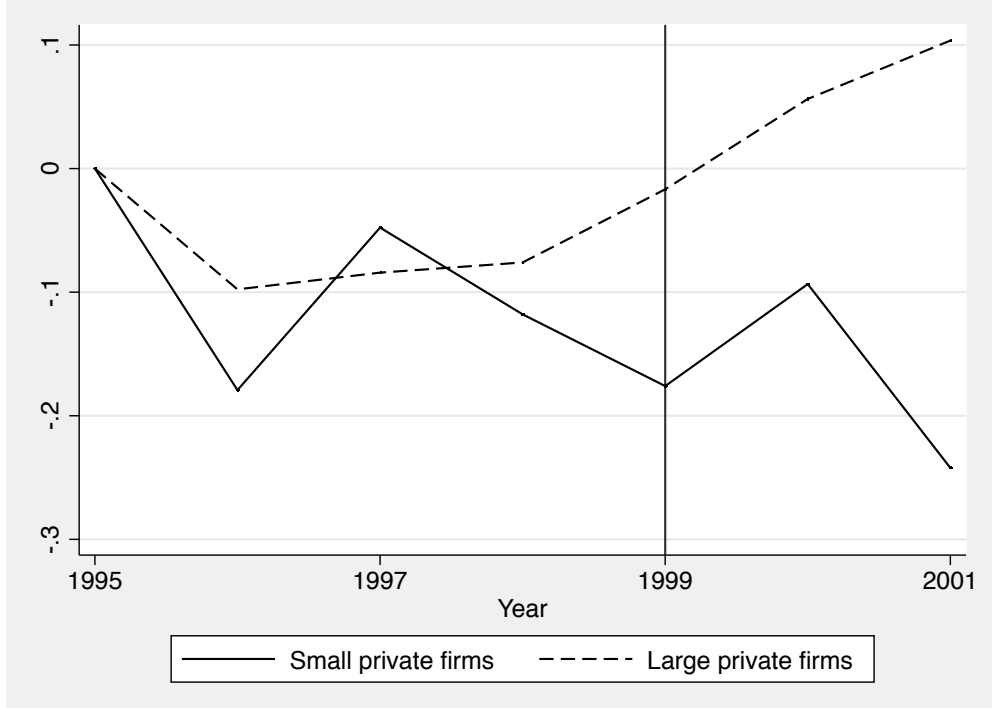

Source: ECHP. The residuals are from the regression of job security on an individual FE, age squared, and dummies for marital status, children in the household and region. The sample is restricted to workers born before September 1949 .

Figure A.6: Job Security Regression Coefficients Over Time for Younger Workers with the Public sector as the Control Group

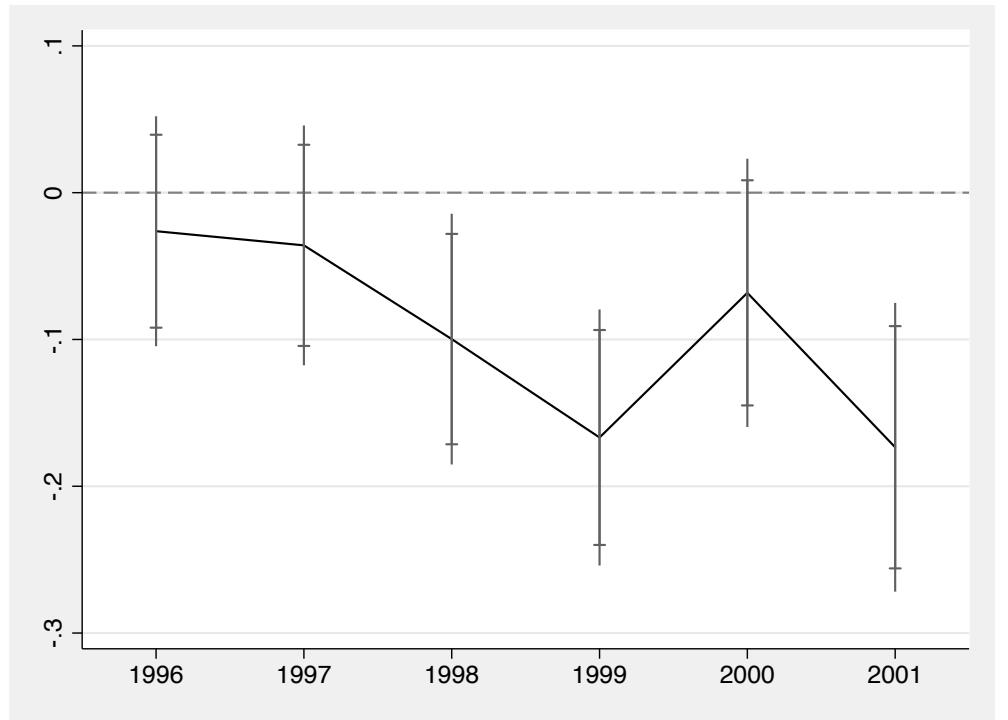

Notes: The confidence intervals are at the $5 \%$ and $10 \%$ levels. The standard errors are clustered at the individual level. The controls include an individual FE, age-squared, and dummies for marital status, children in the household, region and year. The sample is restricted to workers born after December 1951. 
Figure A.7: Job Security Regression Coefficients Over Time for Older Workers with the Public sector as the Control Group

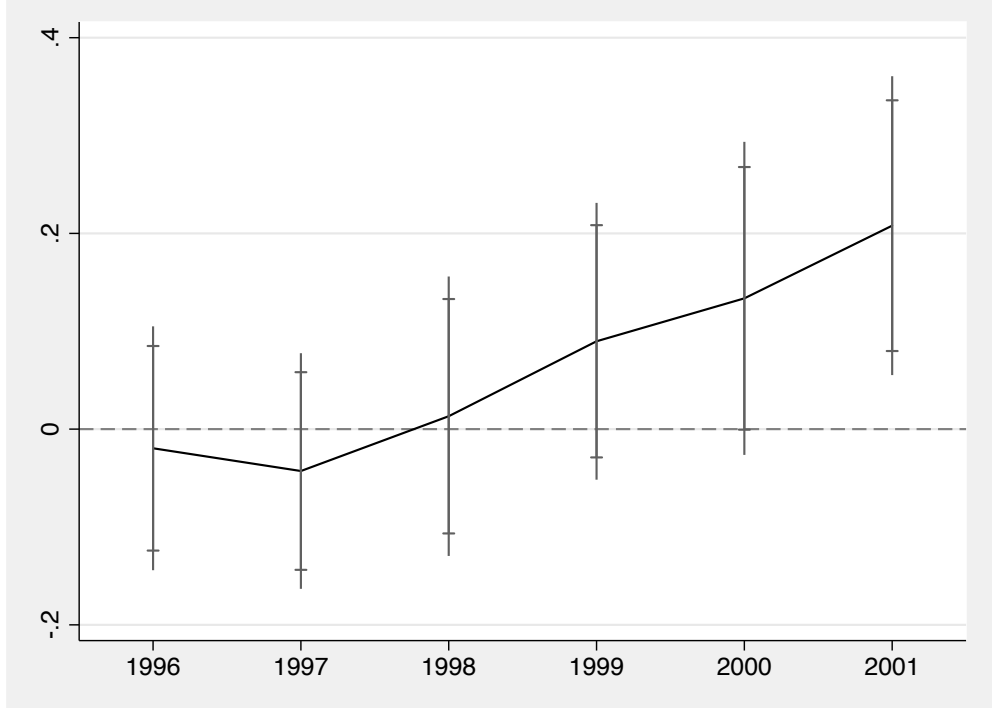

Note: The confidence intervals are at the $5 \%$ and $10 \%$ levels. The standard errors are clustered at the individual level. The controls include individual FE, age-squared, and dummies for marital status, children in the household, region and year. The sample is restricted to workers born before September 1949.

Figure A.8: Job Security Regression Coefficients Over Time for Firms with More than 20 employees

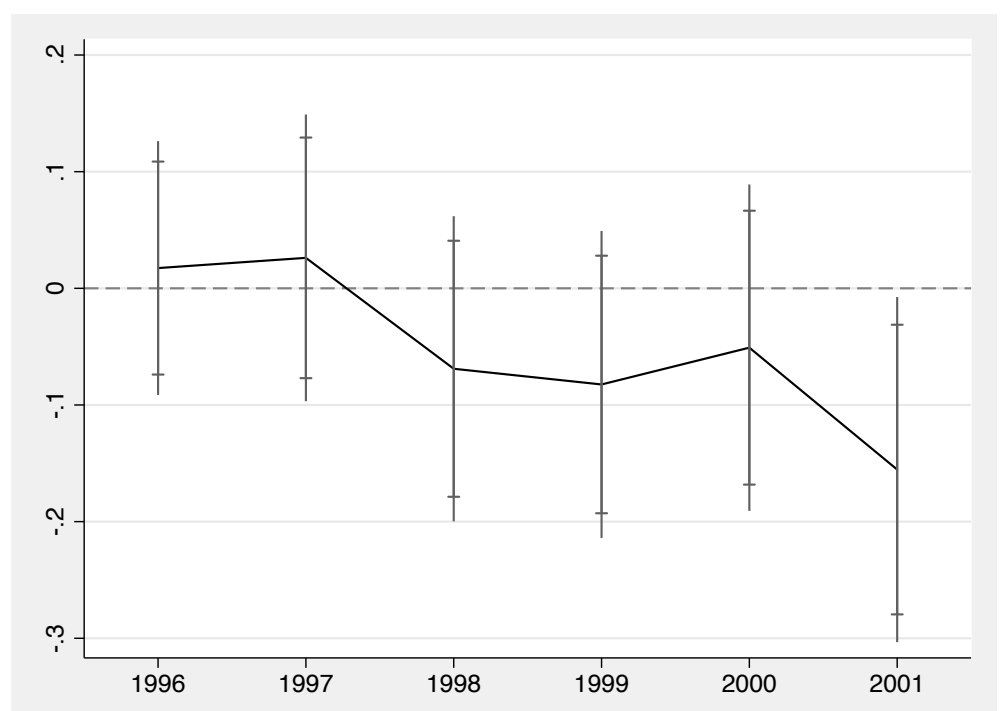

Notes: 9363 observations. The confidence intervals are at the $5 \%$ and $10 \%$ levels. The standard errors are clustered at the individual level. The controls include individual FE, age-squared, and dummies for marital status, children in the household, region and year. 